\title{
Evaluation on green concept of high-rise building design and its architectural feasibility
}

\author{
Johanes Krisdianto ${ }^{a^{*}}$, FX Teddy Badai Samodra ${ }^{\mathrm{a}}$, Mudji Irmawan ${ }^{\mathrm{b}}$ \\ ${ }^{a}$ Department of Architecture, Institut Teknologi Sepuluh Nopember, Kampus ITS Sukolilo, Surabaya, Indonesia \\ ${ }^{b}$ Department of Civil Engineering, Institut Teknologi Sepuluh Nopember, Kampus ITS Sukolilo, Surabaya, Indonesia \\ *Corresponding author. Tel.: +628123220455 \\ E-mail address: johaneskrisdianto@gmail.com
}

\begin{abstract}
Recently, the feasibility study on occupancy, building design and its operation are critical issues in building certification. This study evaluates green concept of a high-rise building, Grand Darmo Suite Hotel Surabaya-an awarded on green building as case study, to the architectural feasibility. The modeling using Ecotect Analysis and CFD Fluent program combined with field observation were also conducted to evaluate the building performance. Based on building simulation and the walkthrough survey and audit, the results show that the building has architectural aspect and advantage, it remains in consistent way between the initial planning and the development. In general, the green concept is implemented in organization of space and its use where they are in accordance with the functions and appropriate to building permit. Furthermore, the condition and quality of the finishing material do not interfere the comfort of occupancy.
\end{abstract}

Keywords: architectural feasibility; building permit; green concept; high-rise building

\section{Introduction to the subject}

Regulation of Surabaya Government, shows status of land and/or permit the use of holders of land rights, building permit, proof of ownership of the building specifically for buildings, and acceptance certificate for the specific function of the building (PERDA Surabaya No. 7/2009, 2009). Comfort requirements referred to this regulation include: determining the layout and circulation among spaces, air condition in the room, view, vibration levels, and noise level. Meanwhile, Regulation of Minister of Public Work aimed for the realization of the building that is always reliable and meet the requirements of the administrative and technical requirements of the building in accordance with its function (PERMENPU No. 25/PRT/M/2007, 2007). It also realizes the buildings functional, according to the layout of the building and in harmony with the environment, which is held in an orderly manner to ensure the reliability of technical building, and the creation of legal certainty in the administration.

Building design and its operation are critical issues in building certification. This study analyzes building concept of Grand Darmo Suite Hotel Surabaya as awarded on green building as case study, to the architectural feasibility. Used mostly as a place for rental rooms, a 4 Star Grand Darmo Suite Hotel provides complementary facilities such as a gymnasium, restaurant, and supported by parking areas and infrastructure as supporting facilities. On a micro scale, terms and architectural aspects strongly support the existence of buildings that are located in the South area of Surabaya. Grand Darmo Suite Hotel also become an icon and an attraction for visitors both for building aspect and a minimalist concept which is expected to meet the vertical housing needs in Surabaya. 


\section{Research theory and methods}

Analysis of the feasibility can fulfill the prerequisites of the requirement of the elements of the apartments utility in terms of architectural regulations on feasibility such as aesthetic, comfort and safety (Selowati \& Indryani, 2012). Furthermore, a progrowth building permit policy causes land prices to rise more in municipalities where developable land is scarce and vice versa (Asabere \& Huffman, 2001). On a macro scale, the strategic presence of the hotel is very supportive for all activities associated with the modern residential centers to support the housing sector and trade and to anticipate the development in the growing area of South Surabaya. Referring to the Regulation of Minister of Public Works, Grand Darmo Suite Hotel included in the category as "complex residential building" (PERMENPU No. 29/PRT/M/2006, 2006).

This study conducts evaluation on green concept based on the basic rules defined by Regulation of Minister of Public Work and can be classified as follows: Mass order in the building site, accessibility, building material, aspects of character and architecture style review, spatial outside and inside perimeters, evaluation of building performance, and environmental evaluation (Permen PUPR No. 02/PRT/M/2015, n.d.). Data collected in this study have been conducted based on field observation and walkthrough audit. Moreover, the environmental evaluation is run by modelling simulation using Ecotect Analysis and ANSYS (CFD) Fluent. Based on the classification of buildings or parts of buildings used in planning, implementation or changes required in buildings, the Grand Darmo Suite Hotel is categorized as Buildings Class 4, namely mix residential building. Building class 4 is a residence building. In Detail, the building classification and profile can be seen in Table 1 and Fig. 1.

Table 1. Building classification.

\begin{tabular}{|c|c|c|}
\hline No. & Aspect & Explanation \\
\hline A. & Building functions & Mix building occupancy \\
\hline C. & Classification is based on the level of permanence & Permanent with a period depended on longevity of planned structures \\
\hline E. & $\begin{array}{l}\text { Classification is based on the concept of property } \\
\text { sales }\end{array}$ & Hotel (rental) \\
\hline F. & Classification based on locations & Urban Hotel: Hotel located in urban area \\
\hline H. & Classification based on property system & Individual (condominium): Considerations of the treatment \\
\hline I. & Classification based on service system & $\begin{array}{l}\text { Service apartment: Most of the people staying at the hotel expect the ease of } \\
\text { practicality. }\end{array}$ \\
\hline $\mathrm{J}$. & Classification based on the height of buildings & $\begin{array}{l}\text { High risk hotel / apartment: Consideration of efficiency and optimization of the } \\
\text { land use and height of buildings up to } 40 \text { floors }\end{array}$ \\
\hline $\mathrm{K}$. & Classification by the position of the corridor & Central corridor: Consideration for service system \\
\hline N. & Classification based on vertical achievement & $\begin{array}{l}\text { Elevated: To facilitate the achievement of the vertical access where the height } \\
\text { of the hotel more than } 4 \text { storeys. }\end{array}$ \\
\hline
\end{tabular}

\section{Results and discussion}

\subsection{Mass order in the building site}

Based on the planning document images and field observations, the building mass are ordered in linear organization that is sensitive to the presence of the site. The site is used efficiently by maximizing the function of space between commercial and residential with vertical arrangement. Location of Grand Darmo Suite Hotel also meets to the provisions footprint by IMB (building permit) with building regulations as follows: Land use: housing and supporting facilities; KDB 50\%; KLB 600\%; and the level of 13-storeys building (Fig.1). 

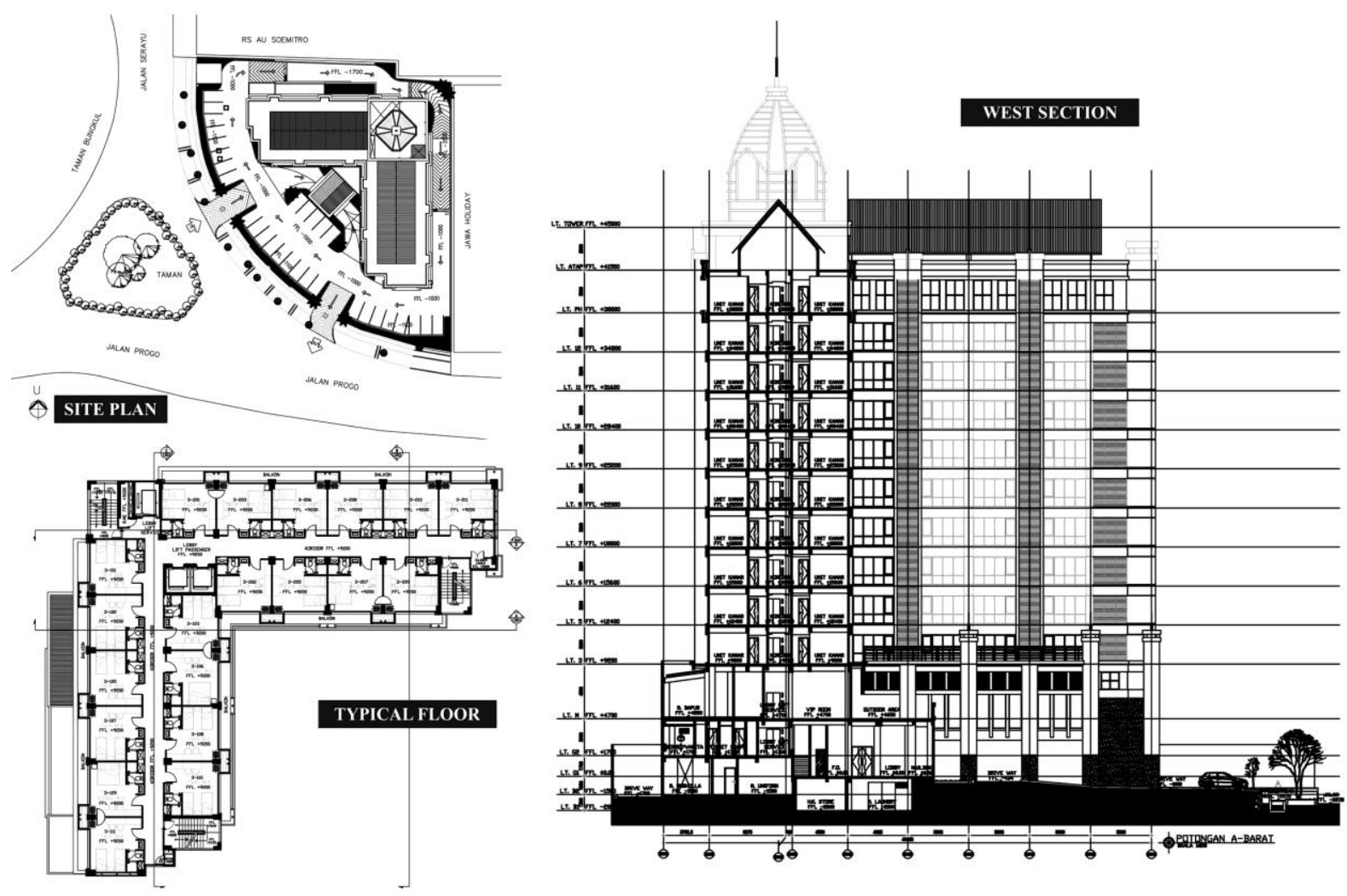

Fig. 1. Building profile.

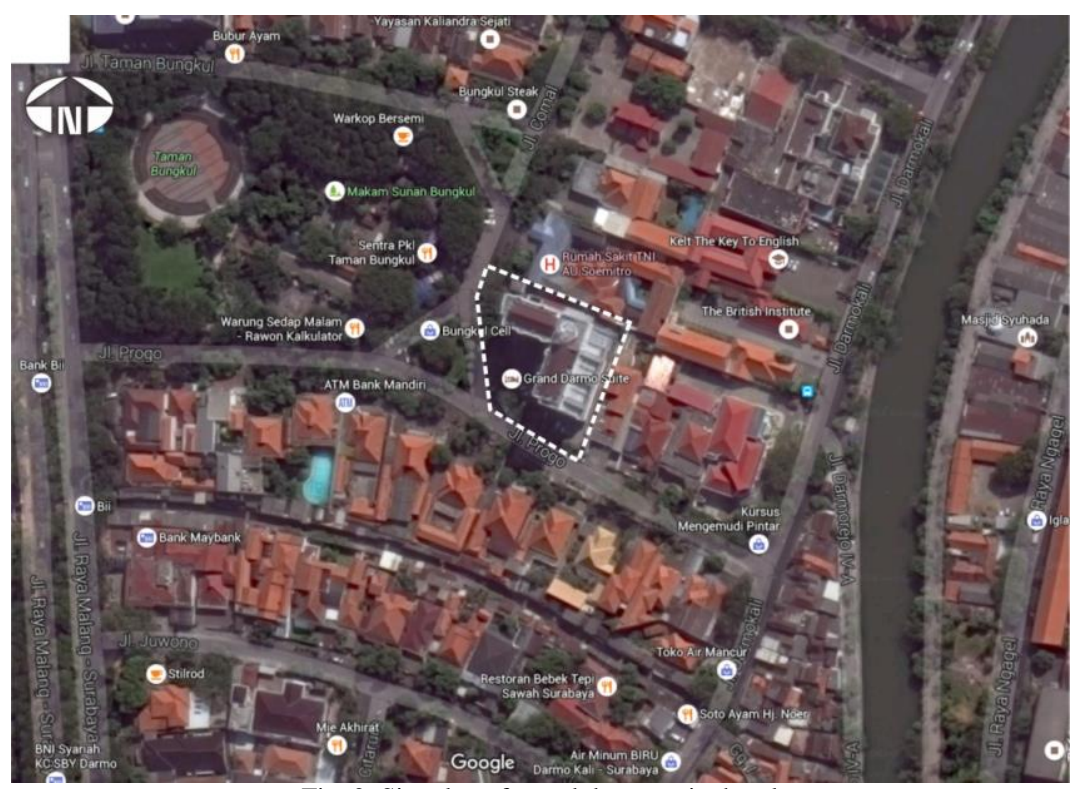

Fig. 2. Site plan of grand darmo suite hotel 


\subsection{Accessibility}

The location should consider the accessibility from both inside and outside of the city. This relates to the quality of the roads, the safety factor from the accident and the current circulation of vehicles that do not interfere with the achievement of the site. Access of the Site is located at Jl. Raya Darmo which is an exclusive area in Surabaya, making it suitable for building Hotel Grand Darmo Suite integrated with residential and commercial district in Raya Darmo street and Bungkul Park. Site can access main road, Darmo street, which is also a main access into and out of Surabaya (Fig. 2). Circulation of vehicles is designed by setting up the driveway leading to the respective of every entrance for visitors and owners. Circulation pedestrian is set up by making the relationships between the purposes of access to and from the parking area or service lift to a height of each floor. In addition, the site can also be reached by user because it has provided quite comfortable pedestrian areas at the side and in front of the site. The accessibility of buildings in the area Grand Darmo Suite Hotel has guaranteed: Ease and clarity entrance for vehicles and pedestrians, comfort and safety for pedestrians and no interruption of the circulation of vehicles in the surroundings of the site.

\subsection{Building material}

In general, evaluation to the building materials are good as presented by Table 2 . It indicates, the consideration of comfort, safety and the maintenance of material is main priority on green concept of this building.

Table 2. The use of material on building.

\begin{tabular}{|c|c|c|c|}
\hline No. & Component & Hotel & Assessment \\
\hline 1. & Roof & Steel Frame & Good \\
\hline 2. & Wall & $\begin{array}{l}\text { Grilled Andesite Stone Bakar 300x600; } \\
\text { Grilled Aluminium Clear Anodized; } \\
\text { Glass Fiber Reinforced Cement, finishing of Paint: Jotashield; } \\
\text { Glass Window 3"Aluminium, Clear Anodized 1500x1500, 3500x2300, 1500x2500, 770x2500; } \\
\text { Lightweight brick wall 75mm, 100mm, Wall Ceramic Creta Grey Décor/Basic 300x600, Wall } \\
\text { Ceramic Granite Tile } 600 \times 600\end{array}$ & Good \\
\hline 3. & Plafond & $\begin{array}{l}\text { Gypsum Board 9mm, finishing of Paint: Majestic Royal Mat; } \\
\text { Expose Concrete, finishing of Paint: Majestic Royal Matt; } \\
\text { Gypsum Board 9mm, finishing of Paint: Majestic Country White; } \\
\text { Calsiboard } 6 \mathrm{~mm} \text {, finishing of Paint: Majestic Country White }\end{array}$ & Good \\
\hline 4. & Floor Finishing & $\begin{array}{l}\text { Carpet Tile Metropolitan Grey 500x500; } \\
\text { Granite Tile } 600 \times 600 \\
\text { Screed Sealer; } \\
\text { Ceramic Amazon Black } 334 \times 667\end{array}$ & Good \\
\hline 5. & $\begin{array}{l}\text { Emergency } \\
\text { Stairs }\end{array}$ & Wall: Brick, Floor: Screed Sealer & Good \\
\hline 6. & $\begin{array}{l}\text { Door and } \\
\text { Window }\end{array}$ & $\begin{array}{l}\text { Frame: Aluminum 3"; } \\
\text { Clear glass } 6 \mathrm{~mm}\end{array}$ & Good \\
\hline
\end{tabular}

\subsection{Aspects of character and architecture style review}

The facade of the building reflecting the function is intended as an emphasis of design as modern residential building (Fig. 3). It is seen from the use of color in layout of the building. The impression is a massive building in the shape but seems light and dynamic through the building envelope material. The concept of the building mass considers optimization of land and space requirements. Therefore, the layout of the building mass adapts to the shape of the existing site as well as the view that there can be used maximally. Building mass order is applied through the basic geometric shapes such as square, mass placement of Grand Darmo Suite Hotel responds the site, which is facing to the Serayu street. The mass of Grand Darmo Suite Hotel is designed based on consideration follows: Attractive: to attract visitors, geometric: an effective and efficient space, and dynamic (not boring). The outdoor space has been planned together with the mass of the building that has linear organization, so that the 
concept of the building mass of the building Hotel Grand Darmo Suit can be concluded: Responding to view around the building and responding to the skyline around the building

\subsection{Spatial outside and inside perimeters}

Concepts in main entrance, circulation has been planned to solve the traffic jam. Vehicle circulation path in outside of the building is from main road (Raya Darmo street) to the main access Grand Darmo Suite Hotel in Progo street with asphalt and paving material to the outdoor parking area. Meanwhile, the softscape elements used in a hotel environment are trees as a component element of the ground cover, the aesthetic elements, steering elements, shade or obstructions, good wind barrier, thermal barrier, and the barrier of sound (noise). In the layout where Grand Darmo Suite Hotel built, there are trees steering the road planted in the middle of the Progo and Serayu three-way junction streets (Fig. 4.). Although limited types of vegetation planted in the site area, Grand Darmo Suite Hotel utilizes Bungkul park as part of its landscape.

Hardscape elements cover street furniture, which serve as a director, the circulation path, aesthetic elements, and the orientation center. There are sidewalks that extend in front of the building as a property line marker. Rooms are integrated with the mass of the building that has the characteristics of a linear organization. In preserving the design theme setting, surroundings housings reinforce the character of the building while strengthening the quality of the view. Motor vehicle parking is placed on the left side of the building. Parking area can accommodate cars in sufficient quantities, with a total of 40 car parking lots and 30 parking lots for motorcycles. To reach the parking lot, one point facing the entrance gateway is provided.

Structuring of space within the building are based on the plot or layout, space and inside/outside corridors, circulation and emergency stairs, the main door and entrance in each floor of the building and the location of the supporting vertical transportation. All are designed in order to meet with the rules of allotment of the commercial and residential with emphasis on a sense of comfort for visitors and residents. Smooth circulation of visitors, fresh air circulation and lighting as well as the most important are in accordance with the provisions of the ease and security evacuation and fire protection. The horizontally zoning could be described as follows: Public Zone, namely: the parking area, minimart, restaurants and gymnasium; Zone semi-public, namely: lobby; Zone of private, namely: unit hotel room, corridor; and Zone service, the service zone, such as a drop of area and Genset room.

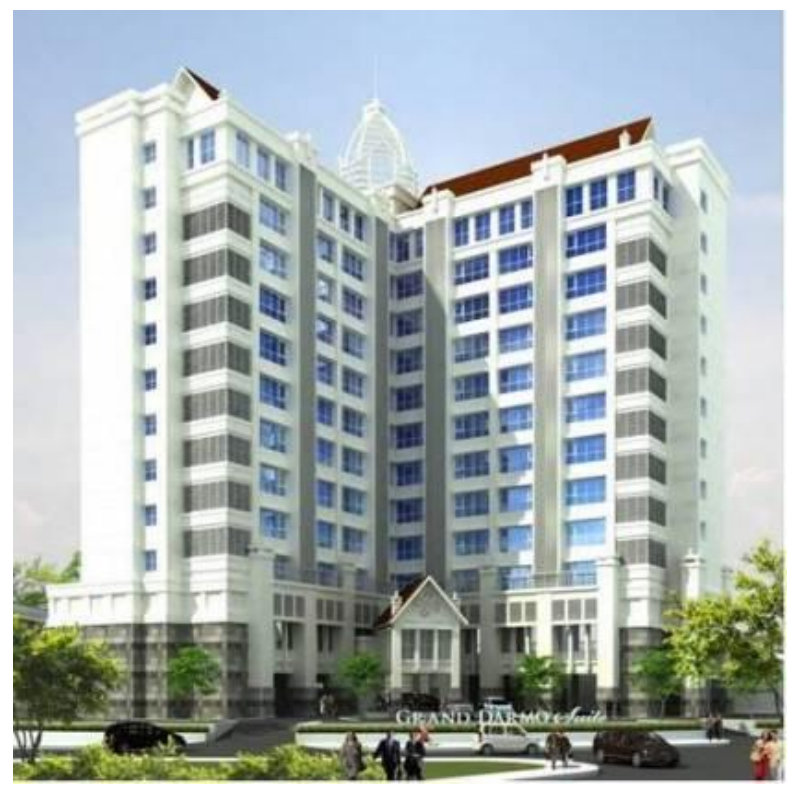

Fig. 3. Building envelope. 


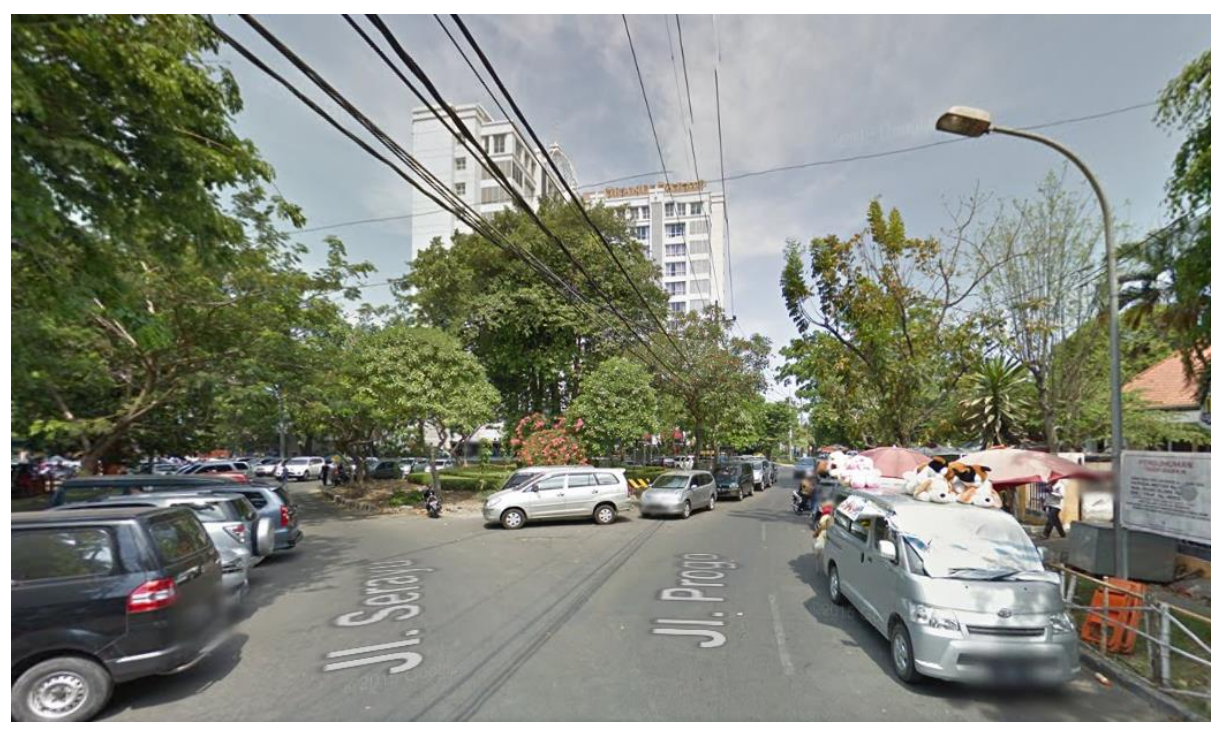

Fig. 4. The use of vegetation.

\subsection{Evaluation of building performance}

Study on total building performance and integration is making evaluation on building performance associated with the demands of comfort and health in building. For this purpose of obtaining the guarantee of building feasibility, the examination of the design document (as built drawings) and field observations should be conducted.

The design concept related to building performance of Grand Darmo Suite Hotel can be explained as follows:

1. Showing the impression of a residential building with a minimalist form of technology.

2. Making the requirements priority and comfort of living-room space, both inside and outside of the rooms.

3. Featuring seven main elements in the architecture, namely:

- Form: applied through a solid mass arrangement with openings that create the impression of light and mass order following the pattern of the way or surroundings building.

- Dimensions: adjust the dimensions of the building mass and spaces in the building in accordance with its activities.

- Color: use of bright colors that express an interesting form of simple and minimalist residential.

- Texture: the texture of the material with a combination of dynamic minimalist effects the combination of the use of solid material (concrete) and glass.

- Position: building arrangement is centered relatively to the composition and configuration of the building can be directed to create a public space.

- Orientation: the orientation of the building follows the access to the city, as well as the orientation of the sun path as a source of natural lighting.

- Inertia visual: building a stable shape in terms of its proportion to the part of the building as a sculpture and is shown to be a point of interest.

The facade of the building reflects the function of which is intended as a design emphasis of a modern residential building. It can be seen from the use of the use of tempered glass on the front of the building which is dominant as a dynamic structural element. The impression is massive in the shape but seems light and dynamic through the building envelope material. In detail, the results of building performance evaluation can be explained in Table 3 below. 
Table 3. Building Performance Parameter.

\begin{tabular}{l} 
Aspect \\
\hline Spatial \\
Basic standard dimensions for safety \& comfort \\
Ergonomics factors: \\
- The toilets or public toilets must be equipped with handrail which have \\
position and height adjusted for wheelchair users and the disabled \\
- The location of tissue paper, water, tap water or shower and facilities such as \\
soap and hand dryers should be installed so that is easy to use by people who \\
have physical limitations and could be reached by a wheelchair user. \\
- All faucets should use a lever system mounted on the sink, etc. \\
- Materials and completion of the floor must not be slippery. \\
- The door must be easily opened and closed by wheelchair users. \\
Height of the room at least $2.3 \mathrm{~m}$ ( $7 \mathrm{ft}, 6$ inches) with the ceiling at least $2 \mathrm{~m}(6$ \\
feet, 8 inches) above the floor level. \\
Ease of accession \\
Signage \\
Aesthetic design \\
Thermal \\
Standard comfort air temperature \\
Room humidity between $50 \%$ - $60 \%$ \\
Consideration of energy conversion \\
When the air temperature $>30^{\circ} \mathrm{C}$ needs to use tools such as Air Conditioning, \\
fan, etc. When the outside air temperature $<18^{\circ} \mathrm{C}$ need to use heaters. \\
When humidity workspace $>95 \%$ need to use a dehumidifier tool. When \\
humidity workspace $<65 \%$ need to use a humidifier (eg, aerosol-forming \\
machine) \\
Ventilation
\end{tabular}

\section{Acoustic}

Isolating the source of noise

Comfort in communicating

Suitability in material and component selection

Comfortable threshold of human hearing between $30 \mathrm{~dB}-60 \mathrm{~dB}$

The noise level in the room up to $85 \mathrm{~dB}$

The room used for activities may not resonate, the resulting sound quality to be clear and non-echoic

Recommended reverberation time refers to the medium frequency $(500 \mathrm{~Hz}$ or $1000 \mathrm{~Hz})$.

\section{Visual}

Minimizing visual barriers and eye strain

There is no direct glare
Condition on Location

Meet the rules of the dimensions of space Ergonomic factors and accessibility are complied
Assessment

Suitable/Good

Suitable/Good

$2.8 \mathrm{~m}$ high space has met minimum height requirement of space

Easy reached access to the emergency stairs and other supporting facilities

Available

Designed

Air conditioning setup adapted to the needs Room humidity $\pm 50 \%$

Have used the split AC wall in the living room, the rooms and public areas (using as cooler and humidifier)

There are exhaust fans on each floor

Suitable/Good

There is a window on the corridor as air circulation

Suitable/Good

There is the sound insulation

Unit fairly impermeable hotel and not noisy

Suitable/Good

Suitable/Good

Available

Field measurements of noise levels between 57-63 dB

Noise room below the maximum threshold There are no echo

Suitable/Good

Suitable/Good

Suitable/Good Suitable/Good

Accommodated

Suitable/Good

The layout window is not directly facing to the public space, reducing glare No glare

Suitable/Good

Suitable/Good

Lighting level of at least 2000 lux 


\begin{tabular}{|c|c|c|}
\hline Aspect & Condition on Location & Assessment \\
\hline The use of color as color display and material impulses & $\begin{array}{l}\text { Color-rich impulses (shown by the colors } \\
\text { orange, yellow, red, green and purple) }\end{array}$ & Suitable/Good \\
\hline The use of color character "cool." & Neutral color: color - gray, brown and blue & Suitable/Good \\
\hline There are doors, windows and light as well as views of the elements of a space & $\begin{array}{l}\text { Each unit has a view towards the outside } \\
\text { and there is a window }\end{array}$ & Suitable/Good \\
\hline Ease of orientation and introduction to space & $\begin{array}{l}\text { The halls seemed well organized in } \\
\text { accordance with the architectural rules }\end{array}$ & Suitable/Good \\
\hline \multicolumn{3}{|l|}{ Building Durability } \\
\hline Resistance and long-term system on material selection & $\begin{array}{l}\text { The main structural materials used: } \\
\text { concrete, metal }\end{array}$ & Suitable/Good \\
\hline Ease of maintenance per part or complete & Accommodated & Suitable/Good \\
\hline \multicolumn{3}{|l|}{ Cleanliness Assessment Standards } \\
\hline $\begin{array}{l}\text { - Plafond } \\
\text { - Glass }\end{array}$ & $\begin{array}{l}- \text { Clean, no stains, no dust, no spider web } \\
\text { - Clean, clear, clear, no dirt, no stains, clean } \\
\text { the glass frame }\end{array}$ & Suitable/Good \\
\hline - Switches and Sockets & - Not dusty, not stained & \\
\hline • Furniture & $\begin{array}{l}\text { - Clean, no dust, not stained, when swabbed } \\
\text { no imprint, no trash, no spider web }\end{array}$ & \\
\hline $\begin{array}{l}\text { Stairs: } \\
\text { - Railing } \\
\text { - Terrace } \\
\text { - Parks } \\
\text { - Floor }\end{array}$ & $\begin{array}{l}\text { - Lush, tidy, beautiful } \\
\text { - Clean, no garbage, no dirty ground/puddle }\end{array}$ & \\
\hline $\begin{array}{l}\text { Toilet: } \\
\text { - Space: no fishy odor, urine and rancid } \\
\text { - Mirror glass: clear, bright, not dull, not stained, not wet } \\
\text { - Closet: flowing smoothly, no stains, no water spots around it, no odor } \\
\text { - Faucets: not stain, not wet, not dull } \\
\text { - Handle Door: clean, no stains, shiny } \\
\text { - Urinal: clean, no stains, no odor, no rust } \\
\text { - Doormat: not dusty, not wet, no litter, no odor }\end{array}$ & $\begin{array}{l}\text { No: stench, urine and rancid, clear, bright, } \\
\text { not dull, not stained, not wet, not dusty }\end{array}$ & Suitable/Good \\
\hline $\begin{array}{l}\text { Stairs: } \\
\text { - Railing: no dust, no stained, no imprint when swabbed } \\
\text { - Terrace: not dusty, not stained, no stains } \\
\text { - Floor: clean, no rubbish, no dirty ground, there are no pools } \\
\text { - There are doors, windows and light as well as views of the elements of a space }\end{array}$ & & Suitable/Good \\
\hline
\end{tabular}




\subsection{Environmental Evaluation}

The evaluation to the air movement around building using ANSYS (CFD) Fluent shows that potency of heat reduction by optimizing the air movement has been conducted by building design. As shown in Fig 5, with wind direction from the South area (as result of field measurement), building's L-shape supports the active ventilation (split air conditioner) to reduce the heat accumulation in indoor environment. The high pressure of higher level of floors also helps the vertical effect of solar radiation to the building envelope of high-rise building (Fig. 5 and Fig. 6). The evaluation to the daylight analysis around building using Ecotect Analysis shows that potency of the daylight is very low because of the building design. The building is for hotel and it needs less daylight for the room except the ground floor (Fig.7).

(a)

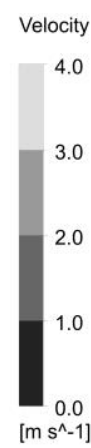

(a)

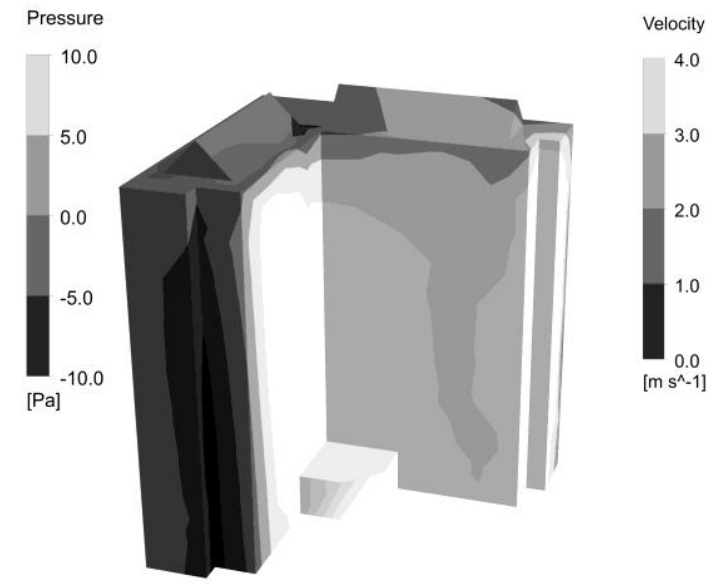

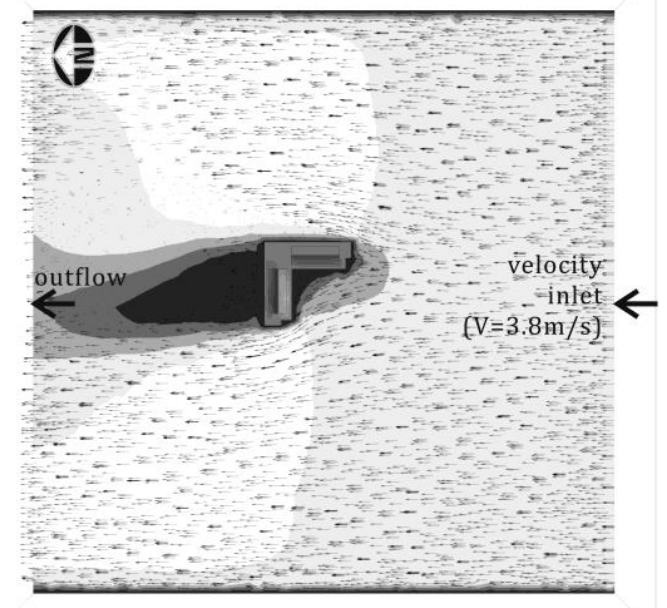

(b)

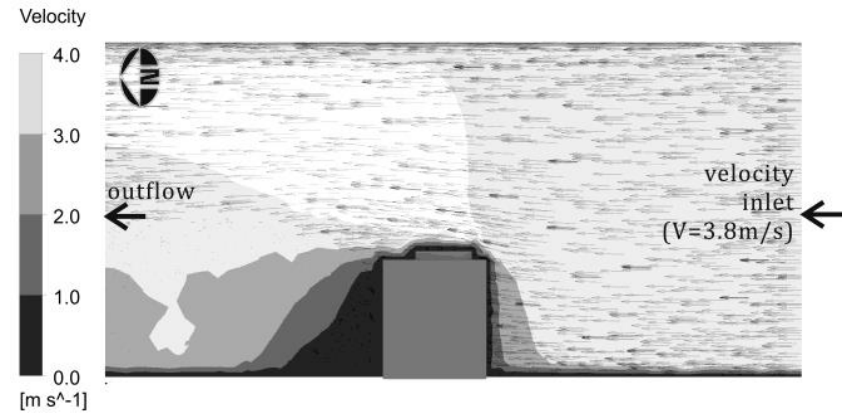

Fig. 5. air movement in building (a) top view; (b) front view (ANSYS Fluent Result).

(b)

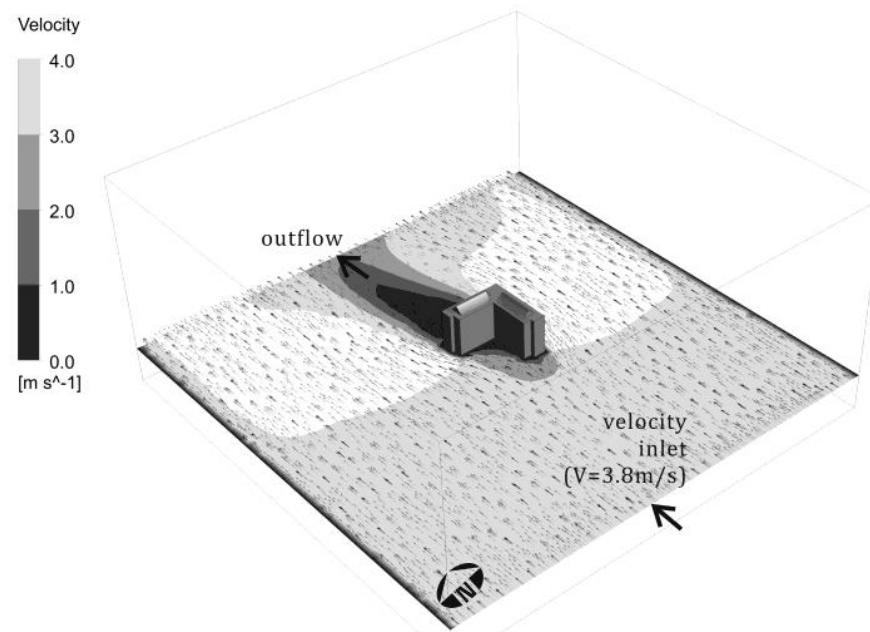

Fig. 6. (a) air pressure in building envelope (b) 3D air movement in building (ANSYS Fluent Result). 


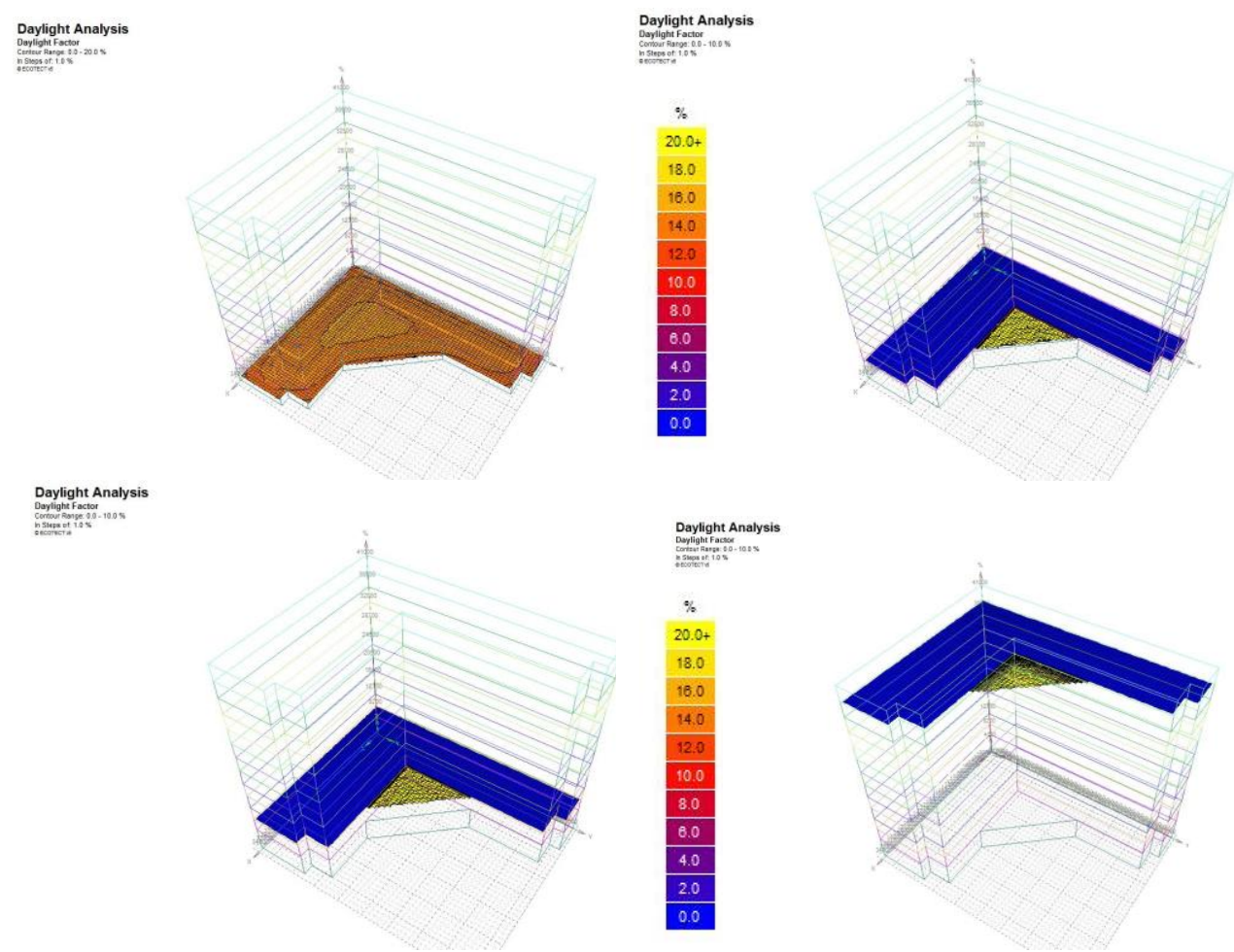

Fig. 7. Daylight analysis effect on building (Ecotect Analysis result).

\section{Conclusions}

The building has architectural aspect and advantage, it remains in consistent way between the initial planning and the development. All aspects, spatial, thermal, IAQ, acoustic, visual, building durability, and cleanliness assessment standards are suitable or in good condition. The building shape accommodates the potency of natural ventilation assistance for air conditioning. The circulation paths or corridors and evacuation facilities have been planned and implemented in accordance with emergency access to a fire hazard. In general, the green concept is implemented in organization of space and its use where they are in accordance with the functions and appropriate to building permit. Furthermore, the condition and quality of the finishing material do not interfere the comfort of occupancy.

\section{Acknowledgment}

This study was a part of the Feasibility Study Project to the Grand Darmo Suite Hotel. The authors gratefully acknowledge to Engineering Department for the technical support.

\section{References}

Asabere, P. K., \& Huffman, F. E. (2001). Building Permit Policy and Land Price Distortions: Empirical Evidence. Journal of Housing Economics, 10(1), 59-68. https://doi.org/10.1006/jhec.2001.0278

PERDA Surabaya No. 7/2009. Bangunan, Pub. L. No. 7/2009 (2009).

Permen PUPR No. 02/PRT/M/2015. Bangunan Gedung Hijau, Pub. L. No. 02/PRT/M/2015.

PERMENPU No. 25/PRT/M/2007. Pedoman Sertifikat Laik Fungsi Bangunan Gedung, Pub. L. No. 25/PRT/M/2007 (2007). Indonesia.

PERMENPU No. 29/PRT/M/2006. Pedoman Persyaratan Teknis Bangunan Gedung, Pub. L. No. 29/PRT/M/2006 (2006). Indonesia.

Selowati, D. T., \& Indryani, R. (2012). Analisa Kelayakan Huni Apartemen The Via and The Vué Surabaya Dari Segi Arsitektural. Institut Teknologi Sepuluh Nopember. 
